\title{
Strategic accumulation of patents in the pharmaceutical industry and patent thickets in complex technologies - two different concepts sharing similar features
}

\author{
Published in IIC - International Review of Intellectual Property and Competition Law (June 2017, \\ Volume 48, Issue 4, pp 385-404)
}

\author{
Olga Gurgula \\ Lecturer in IP Law, Brunel Law School, Brunel University London \\ Visiting Fellow, Oxford Martin School, University of Oxford
}

\begin{abstract}
This paper discusses the problem of strategic accumulation of patents in the pharmaceutical industry. In the academic legal discussion this strategy is often confused with the notion of patent thickets. It will be argued, however, that these two strategies, although sharing similar features, are, nevertheless, distant issues and therefore require different analysis. The paper will first discuss the notion of patent thickets in complex technologies, including their definition, factors that contribute to their growth, examples of patent thickets and how the problem of patent thickets in complex technologies is currently being resolved. The subsequent part will analyse the specific strategy of pharmaceutical companies identified by the European Commission as 'patent thickets' in its Pharmaceutical Sector Inquiry. It is argued that this strategy of pharmaceutical companies is not, in fact, 'patent thickets' according to the classical, traditional meaning of the term, and should, therefore, be detached from the notion of patent thickets. This definition is misleading, and because of the incorrect qualification of this practice by the Commission and the academic community, it has not received adequate analysis under competition law. Therefore, the aim of this paper is to identify what patent thickets are and to dissociate strategic accumulation of patents in the pharmaceutical industry from the concept of patent thickets. It is hoped that the conclusions made in this paper will help to attract attention of the competition authorities to the problem of strategic accumulation of patents for the benefit of the consumer welfare.
\end{abstract}

Keywords: patent thickets, strategic accumulation of patents, perindopril, anticompetitive practices, the pharmaceutical industry, patent wars

\section{Introduction}

The notion of strategic patenting is neither new nor inherent only to the pharmaceutical industry. However, the pharmaceutical industry is a sensitive one, which combines private and public interests and therefore falls under the tight control of competition authorities. As a result of the Pharmaceutical 
Sector Inquiry, which was undertaken in 2008, the European Commission revealed that these practises may delay or even block generic competition and the launch of innovative medicines. Such findings have fuelled debates as to whether these strategies may be deemed unlawful and violate competition rules, while also being justifiable business practices under patent law. However, despite such a heated discussion this problem has not received adequate attention from the competition authorities. This lack of attention allows pharmaceutical companies to abuse the patent system without any fear of prosecution extending their market monopoly and charging exorbitant prices on their medicinal products.

This paper will address such form of strategic patenting as strategic accumulation of patents. In the academic legal discussion this strategy is often confused with the notion of patent thickets. It will be argued, however, that these two strategies, although sharing similar features, are, nevertheless, distant concepts and therefore require different analysis. In section I the discussion will start with the notion of patent thickets, as it exists in complex technologies, including definition, factors that contribute to their growth, examples of patent thickets and how the problem of patent thickets in complex technologies is currently being resolved. Section II will analyse the specific strategy of pharmaceutical companies identified by the European Commission and named 'patent thickets' in its Pharmaceutical Sector Inquiry. It is argued that this strategy of pharmaceutical companies is not, in fact, an instance of 'patent thickets' according to the classical, traditional meaning of the term, and should, therefore, be detached from the notion of patent thickets. The term 'patent thickets' was used by the EU Commission to describe a specific strategic patenting practice of pharmaceutical companies, that has the features of accumulation of patents with the anticompetitive exclusionary purposes. Section III will explain that the definition of strategic accumulation of patents as patent thickets is misleading, and because of the incorrect qualification of this practice by the Commission and the academic community, this practice has not received adequate attention of the competition authorities. Section IV will underline the importance of dissociation of these two concepts. Section V will outline the role of patent law and competition law in strategic accumulation of patents. The paper will conclude with the hope that this analysis will help to attract attention of the competition authorities to abuses of the patent system in the form of strategic accumulation of patents in the pharmaceutical industry and will contribute to the solution of this problem for the benefit of consumers.

\section{Patent thickets in complex technologies}

Current discussion on patent thickets is as complex and intricate as patent thickets themselves. The main theme of this discussion may be roughly divided into three sections: (a) what are patent thickets?; (b) factors that contribute to the phenomenon of patent thickets; and (c) mechanisms aimed at resolving the patent thickets problem.

\subsection{What is a patent thicket?}

Innovation has a cumulative nature. This means that no inventor can claim that they were the first person to invent without crediting the prior inventors who made their invention possible. To put it differently, innovation may today be viewed as a huge scientific pyramid, where each of the researchers adds his block to its creation. ${ }^{1}$ On the level of basic research, credits to prior researchers are often given in the

Carl Shapiro, 'Navigating the Patent Thicket: Cross Licenses, Patent Pools, and Standard-Setting' in Adam b. Jaffe et al. (eds), Innovation Policy and the Economy 1, 120 (National Bureau of Economic Research, 2001) <faculty.haas.berkeley.edu/shapiro/thicket.pdf> (accessed 20 July 2016). 
form of citation. ${ }^{2}$ However, when it comes to the product development stage, the building blocks of the pyramid may become obstacles in the form of patents, requiring the manufacturer to give credit to each of the patent holders in the form of licences. ${ }^{3}$ This in turn begs the question: do the legal system and institutions established to promote and stimulate innovation comply with their mission? Or do they in fact produce the opposite result of stifling and discouraging innovation? When dealing with these questions, legal scholars have come to the conclusion that the patent system, in the way it currently works, creates a specific phenomenon known as 'patent thickets'.

The phrase 'patent thickets' is a descriptive term which highlights issues that new entrants to the market may face when attempting to innovate within, or enter into, a technology space with existing intellectual property rights. ${ }^{5}$ In legal literature, they are often equated with the anticommons after Professor Michael Heller's theory of anticommons in real property, which arises when there is excessive fragmentation of ownership interests in a single parcel of land. ${ }^{6}$ In 1998 Professor Heller developed a theory of anticommons property ${ }^{7}$ in order to explain the conundrum of empty storefronts and full kiosks in Moscow. It was suggested that anticommons property is 'the mirror image of commons property' ${ }^{8}$ Thus, in commons, multiple owners are each endowed with the privilege to use a given resource, and no one has the right to exclude another. When too many owners hold such privileges of use, the resource is prone to overuse - this is known as the tragedy of the commons. In the anticommons, according to Professor Heller, multiple owners are each endowed with the right to exclude others from a scarce resource, and no one has effective privilege of use. Thus, the tragedy of the anticommons exists when too many owners hold such rights of exclusion, since the resource is prone to underuse. ${ }^{9}$

In line with the theory of the anticommons, Shapiro describes patent thickets as 'a dense web of overlapping intellectual property rights that a company must hack its way through in order to actually commercialise new technology'. ${ }^{10}$ Other definitions, given by different scholars, are very close to Shapiro's definition and highlight the problem of fragmentation of property rights and numerous owners possessing blocking rights. ${ }^{11}$ Thus, it seems that it is commonly agreed that patent thickets arise when a large number of patents with overlapping claims are owned by multiple parties.

\begin{tabular}{|c|c|}
\hline 2 & ibid. \\
\hline 3 & ibid. \\
\hline 4 & $\begin{array}{l}\text { ibid. Alternative terms that might be found in the literature, which infer the same meaning, are 'patent floods' (See } \\
\text { Mattias Ganslandt, 'Intellectual Property Rights and Competition Policy' (2008) } 726 \text { IFN Working Paper } 12 \\
\text { 'multiplicity of patents, referred to as "patent thickets" and "patent floods"') and 'patent clusters' (See European } \\
\text { Commission, 'Pharmaceutical Sector Inquiry, Preliminary Report' (2008) 9 'One commonly applied strategy is filing } \\
\text { numerous patents for the same medicine (forming so called 'patent clusters' or 'patent thickets'). }\end{array}$ \\
\hline 5 & Report, 'Patent Thickets' (2011) Intellectual Property Office (UK) 3 <www.ipo.gov.uk> (accessed 20 July 2016). \\
\hline 6 & $\begin{array}{l}\text { See Michael A. Heller, 'The Tragedy of the Anticommons: Property in the Transition from Marx to Markets' (1998) } \\
111 \text { HARV. L. REV. 621. }\end{array}$ \\
\hline 7 & $\begin{array}{l}\text { According to Prof. Heller anticommons property is 'a type of property regime that may result when initial endowments } \\
\text { are created as disaggregated rights rather than as coherent bundles of rights in scarce resources' ibid } 623 \text {. }\end{array}$ \\
\hline 8 & ibid 623. \\
\hline 9 & ibid 622. \\
\hline 10 & (n 1). \\
\hline 11 & 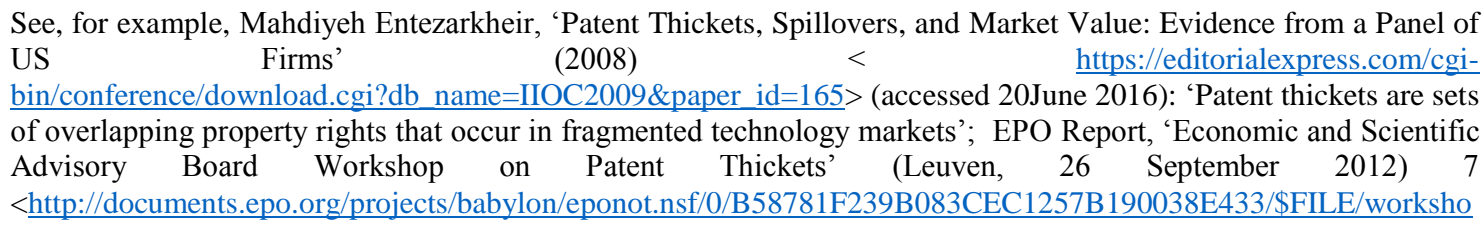 \\
\hline
\end{tabular}


Such a definition fits neatly with the essence of complex technology. Thus, thickets normally consist of patents that protect components of a modular and complex technology. 'Modular' means that different sets of components can be assembled to yield a variety of technological products, while 'complex' means that products consist of tens or hundreds of such modular components. ${ }^{12}$ Each component may be used in several products. ${ }^{13}$ Often there are partial or complete overlaps in the functionality of components and, in this case, the patents protecting the components may also overlap. ${ }^{14}$ If overlapping patents belong to different firms, then a patent thicket exists. ${ }^{15}$

Most importantly, patent thickets are formed unintentionally, ${ }^{16}$ i.e. this dense web of overlapping claims arises and grows without the direct intention of patent holders to create them, but they are formed indirectly as a result of different motives and reasons. The reasons for the creation of patent thickets will be discussed below.

\subsection{Existence of patent thickets in complex technologies and factors that contribute to their creation}

The problem of patent thickets has recently caught the attention of the scientific and engineering community in a number of technological spheres. Considering the way patent thickets are created and how they work, it seems natural that they appear in complex technologies and, therefore, the discussion on patent thickets is always focused on such complex industries as semiconductors, biotechnology, computer software, the Internet, and nanotechnology. ${ }^{17}$ These technologies are cited by legal scholars as harbouring patent thickets. ${ }^{18}$

The important factors that contribute to the growth of patent thickets might be divided into two groups: institutional gaps and business strategies. The institutional factor includes such issues as flows in the work of patent offices (explained by a lack of resources) ${ }^{19}$ that lead to poor examination of patent applications, resulting in a grant of weak patents with overlapping claims, and claims with uncertain breadth or scope.

p_patent_thickets_en.pdf> (accessed 20 July 2016): 'A dense and overlapping set of complementary patent rights...of which at least one patent right is blocking the production of an innovation'. However, not everyone is in favour of such this analogy. Sir Robin Jacob, for instance, argues that the term 'patent thickets' is 'emotive, suggesting that there is something wrong with the present position.' Robin Jacob, 'Patent thickets: a paper for the European Patent Office Economic and Scientific Advisory Board Meeting' (2013) 8(3) Journal of Intellectual Property Law \& Practice 203. B.H.Hall et al., 'A Study of Patent Thicket' (2013) UK IPO 7.

ibid.

ibid.

ibid.

Gavin Clarkson and David Dekorte, 'The Problem of Patent Thickets in Convergent Technologies' (2006) 1093 Annals of the New York Academy of Sciences 180.

(n 1) 119. See also Dan L. Burk and Mark A. Lemley, 'Policy Levers in Patent Law' (2003) 89 VA. L. REV. 1575, 1625-27; David S. Evans and Anne Layne-Farrar, 'Software Patents and Open Source: The Battle over Intellectual Property Rights' (2004) 9 VA. J.L. \& TECH. 10, 21-23.

B.H.Hall et al. (n 12) 32; Gavin Clarkson and David Dekorte (n 16).

B.H.Hall et al. (n 12) 8. 
Another factor that contributes to the growth of patent thickets is companies' business strategies. ${ }^{20}$ Recent survey evidence suggests that the primary reasons for patenting in complex industries are: (1) to prevent rivals from patenting related inventions (i.e. 'patent blocking'); (2) to use in negotiations with owners of outside patents and technologies; and (3) to deter patent infringement lawsuits. ${ }^{21}$ One of the FTC reports notes that, in certain industries, the large number of issued patents makes it virtually impossible to search all the potentially relevant patents, review the claims contained in each of those patents, and evaluate the infringement risk or the need for a licence. ${ }^{22}$ The owner of any of the multitude of patented technologies can hold up production of the innovative new product. ${ }^{23}$ Therefore, for many firms, the only practical response to this problem of unintentional and sometimes unavoidable patent infringement is to file hundreds of patents each year so as to have something to trade during crosslicensing negotiations. ${ }^{24}$

\subsection{Examples of patent thickets: Patent wars - sewing machines and smartphones}

\subsection{1. $\quad$ Sewing Machine War}

It is assumed that patent thickets are a modern problem that has arisen as a result of vast technological development and increased product complexity. However, the creation of the first patent thickets in patent law history challenges this presumption. ${ }^{25}$ A good classical example of patent thickets is over 150 years old and arose from the invention of the sewing machine in the antebellum era, which led to the famous Sewing Machine War in the 1850s and its eventual transformation into the Sewing Machine Combination of $1856 .^{26}$

The sewing machine, how strange it now sounds to say, is a complex, cumulative invention, much like the smartphone today. The sewing machine was not created by a single person: until it became a successful product, numerous inventors had spent many years of experimentation and had obtained hundreds of patents over the components that would eventually become essential parts of the sewing machine. ${ }^{27}$ As a result of the sewing machine's invention, as one mid-nineteenth century author noted, 'it is now utterly impossible to make a sewing machine of any kind of any practical utility without

$20 \quad$ ibid 22.

21 Cohen, W. M., et al., 'Protecting their intellectual assets: Appropriability conditions and why U.S. manufacturing firms patent (or not)' (2000) 7552 NBER working paper, Cambridge, MA. FTC Report, ‘To Promote Innovation: The Proper Balance of Competition and Patent Law and Policy’ (2003). ibid.

24 (n 16) 5. See also B.H.Hall et al. (n 12) 8, that add also other factors that contribute to the creation and growth of patent thickets, i.e. the cumulative nature of science and as a result the shift to the complexity in many technologies, as well as the assertion of patents by Patent Assertion Entities. To a jurisdiction specific factors that contribute to a growth of patent thickets, but have an implication on other jurisdictions some authors add the strengthening of patent rights with the creation of the Court of Appeal for the Federal Circuit in the US in 1982; the broadening of patent subject matters, like software, where the most of patent thickets arise, and the increase tendency to resolve patent disputes using injunctions.

25 Adam Mossoff, 'The Rise and Fall of the First American Patent Thicket: The Sewing Machine War of the 1850s' (2011) 53 Arizona Law Review 165, 211 < http://papers.ssrn.com/sol3/papers.cfm?abstract_id=1354849> (accessed 20 July 2016). sewing machine industry' (2010) 70 Journal of Economic History 898-920. 
directly infringing several subsisting patents, the validity of which cannot be questioned' ${ }^{28}$ This resulted in massive litigations between numerous patent owners, such as I.M. Singer \& Co., Lerow \& Blodgett and Wilson, Wheeler \& Co. etc., each of which was claiming his rightful slice of the royalty pie. ${ }^{29}$ However, these numerous inventors didn't just make their contribution to a technological development, creating one of the 'epoch-making inventions of America'; ${ }^{30}$ they also made their contribution to a heated academic debate by creating the first American patent thicket.

The outcome of these creations, both the sewing machine and the patent thickets surrounding it, was that the manufacturers could not produce any sewing machine without facing litigation from other patent holders. Therefore, in order to stop this meaningless patent war, which was consuming vast resources in time and money, a simple solution was found: patent owners combined their patents into a patent pool. ${ }^{31}$ The patent pool consisted of several independent companies and nine patents, with the peak at just over $150 .{ }^{32}$ As with modern patent pools, its members were free to compete with each other in the sewing machine market, but they had to cross-license their patents to each other and were obliged to pay licence fees for each sewing machine they produced. ${ }^{33}$ The Combination had enormous success, as it brought to an end the waste of resources on myriad litigations and allowed the production and sale of sewing machines to commence. ${ }^{34}$

\subsection{2. $\quad$ Smartphone patent wars}

The example of the sewing machine patent thicket shows that it's not a modern problem indeed. However, the creators of the first patent thicket could not imagine the scale and multitude of the patent thickets that would emerge 150 years later. The most prominent example of such thickets are the smartphone patent thickets that have spread their branches throughout jurisdictions and involve numerous companies and thousands of patents.

A smartphone is a complex combination of technological components owned by different companies. As the number of players and patented features increase, the transaction costs of assembling a 'completely licensed' smartphone become increasingly burdensome, because the manufacturer has to deal separately with the owner of each feature or patented component. ${ }^{35}$ It is submitted that there is not a single smartphone that has not been accused of patent infringement, with suits being filed against Apple, Samsung, Google, Research in Motion, Microsoft, Nokia, Motorola, HTC and others. ${ }^{36}$ Apple's founder Steve Jobs was widely quoted as having said that one HTC smartphone model was 'grand theft' of Apple's patented features: 'I will spend every penny of Apple's $\$ 40$ billion in the bank, to right this

\footnotetext{
28 ibid. See also Henry Howe, 'Adventures and Achievements of Americans' (Cincinnati, Henry Howe 1859) 159.

$29 \quad$ Adam Mossoff (n 25) 194.

$30 \quad$ ibid.

31 ibid.

$32 \quad$ (n 12) 21.

$33 \quad$ Adam Mossoff (n 25) 195.

34 ibid 195

35 Jeffrey I. D. Lewis, 'The sky is not falling: Navigating the smartphone patent thicket' (WIPO Magazine, February 2013) <http://www.wipo.int/wipo magazine/en/2013/01/article 0002.html> (accessed 20 July 2016).

36 ibid.
} 
wrong. I'm going to destroy Android, because it's a stolen product. I'm willing to go thermonuclear war on this,' Mr Jobs said. ${ }^{37}$

The smartphone patent wars present a labyrinth of lawsuits and countersuits across the globe ${ }^{38}$ and include such countries as the UK, the US, the Netherlands, Japan, Germany, South Korea, Australia, France and Italy. Unlike the sewing machine patent thickets, the smartphone patent thickets have not yet been resolved and it seems unlikely that they will be resolved in the foreseeable future. However, some authors are quite optimistic on this account, stating that 'the sky is not falling' and referring to the Sewing Machine Combination as a solution for smartphones. ${ }^{39}$

The sewing machine and the smartphone are good examples of patent thickets, as they clearly show the distinct features of patent thickets, i.e. numerous inventions owned by different inventors that have to be combined in order to produce a single complex product.

\subsection{Solutions to the problem of patent thickets in complex technology}

The problem of patent thickets is generally considered to be a natural outcome of the patent system functioning and it is usually suggested that it should be resolved by the patent system's mechanisms. ${ }^{40}$ As Sir Robin Jacob noted, 'the thicket problem is simply a natural consequence and cost of the patent system as a whole and nothing can really be done about it ${ }^{, 41}$ therefore, attention should be focused on improving aspects of the patent system. ${ }^{42}$

However, the sewing machine patent thickets examples show that this problem is a story of the successful resolution of a thicket through private mechanisms. The problem of the sewing machine patent thickets was not brought to an end by new laws, lawsuits by public interest organisations, or new regulations at the Patent Office, but rather by the patent owners exercising their rights of use and disposition in their property. ${ }^{43}$

Since then, the market players involved in patent thickets have developed 'business' mechanisms to overcome problems of goods production shutdown that require coordination among right holders. ${ }^{44}$ These are cross-licensing, patent pools and standard setting mechanisms. Thus, when the total number of owners of the conflicting intellectual property rights is small, the patent thicket would normally be

\footnotetext{
37 ibid.

38 Michel A. Carrier, 'A Roadmap to the Smartphone Patent Wars and FRAND licensing' (2012) 2(4) CPI Antitrust Chronicle 7.

39 (n 35).

40 Robin Jacob (11).

41 ibid.

42 ibid.

$43 \quad$ Adam Mossoff (n 25) 170.

$44 \quad$ Shapiro (n 1) 119 'While solving this problem two issues must be cautious about, namely coordination costs and the antitrust regulation that is sensitive when companies in the same or related markets combine their assets or jointly set fees. Antitrust law and enforcement, with its historical hostility to cooperation among horizontal rivals, can easily add to these transaction cost. However, a simple principle of the desirability package licensing for complementary patents but not for substitute patents may ensure that antitrust law will not be violated'.
} 
resolved through cross-licensing. ${ }^{45}$ When more than two parties are involved, however, the transaction costs of cross-licensing between all the parties can be prohibitive, and additional economic barriers such as hold-ups and double marginalisation might exist. ${ }^{46}$ Therefore, in response to these challenges throughout the last 150 years, organisations have attempted to solve the multi-party patent thickening problem by constructing patent pools. Another solution to the patent thickets problem, which resolves the complements problem, is a standard setting mechanism, where participants agree to license all patents essential to compliance with any standard on 'fair, reasonable, and non-discriminatory' terms.

Having discussed the particular features of patent thickets in complex technologies, the causes that contribute to their growth and the mechanisms that can be used to overcome the problem of patent thickets, the following section will now turn to the specific practices in the pharmaceutical industry identified by the Commission as patent thickets. It will be showed that these practices are not patent thickets and that they deserve the special attention of the competition authorities.

\section{Strategic accumulation of patents in the pharmaceutical industry}

The analysis below will show that the phenomenon in the pharmaceutical industry identified by the Commission is distinct from the traditional concept of patent thickets in complex technology industries. Therefore, for the purpose of the antitrust analysis it is important to dissociate these two concepts. As the strategy employed by pharmaceutical companies does not bear all the necessary features of patent thickets, the definition of this practice as patent thickets will be misleading. Therefore, for the purpose of further discussion this practice will be defined as 'strategic accumulation of patents'. This term bears the necessary features of this particular practice, which involves building a multi-layered fence around a basic compound with strategic exclusionary purposes.

\subsection{Do patent thickets exist in the pharmaceutical industry?}

As was mentioned above, discussion on patent thickets has always been focused on complex technologies. With respect to the pharmaceutical industry, it is suggested that thickets are thought to be less prevalent and less problematic. ${ }^{47}$

This lack of attention to the pharmaceutical industry is due to the nature of the technology - most often, it is discrete. ${ }^{48} \mathrm{~A}$ piece of a discrete technology is an active pharmaceutical ingredient (API) and a patent for a drug will normally cover a molecular formula for an API. ${ }^{49}$ Another important feature of the industry is the proprietary nature of APIs ${ }^{50}$ - generally pharmaceutical companies own patents on their inventions either as an initial inventor, or via an assignment. As to licences, according to the empirical

\footnotetext{
$45 \quad$ (n 16) 4.

46 ibid.

47 Georg von Graevenitz et al., 'How to measure patent thickets - A novel approach' (2011) 111(1) Economics Letters 6-9. doi: 10.1016/j. econlet.2010.12.005.

48 Stu Woolman et al., 'Evidence on Patent Thickets in Complex biopharmaceutical technologies' (2013) 53(1) IDEA The Intellectual Property Law Review 6.

49 ibid 6. Barry Werth, 'The Billion Dollar Molecule: One Company’s Quest the Perfect Drug' (1995).

$50 \quad$ Stu Woolman et al. (n 48) 7 .
} 
study on the existence and influence of patent thickets in the biopharmaceutical industry undertaken by Woolman, the most frequent number of licences is zero. ${ }^{51}$ The discreteness of the pharmaceutical technology and its proprietary nature eliminate the need for cross-licensing. ${ }^{52}$ As a result, a company that has a discrete product on the proprietary bases does not normally face any thicket effect.

\subsection{Findings of the European Commission}

How is the above discussion on patent thickets relevant to the findings of the Commission? After its indepth investigation into the pharmaceutical industry in 2008, the Commission concluded that some of the practices used by originator pharmaceutical companies delay generic competition. One of them, according to the Commission, is patent thickets. However, while the Commission identified a specific problem that indeed has the capacity to substantially delay generic competition, it nevertheless erred in the accurate definition of its specific features, i.e. that it is a unilateral practice of pharmaceutical companies focused on restraining competition. This practice is far more hazardous for the market and the ultimate consumer, than patent thickets in complex technologies, and, therefore, requires special attention from the competition authorities.

Moreover, despite the Commission acknowledged that strategic accumulation of patents may affect generic competition, it nevertheless refrained from any legal qualification of this practice in its Report, as well as failed to condemn this practice in its recent Perindopril decision. ${ }^{53}$ However, as will be shown further, strategic accumulation of patents calls into question the legitimacy of this practice under competition law. In particular, it is suggested that competition law rules on abuse of dominant position under Article 102 TFEU should be applicable to strategic accumulation of patents when this practice eliminate generic competition in an anti-competitive way and have adverse impact on consumer welfare..$^{54}$

\subsection{What is strategic accumulation of patents}

Strategic accumulation of patents enables pharmaceutical companies to artificially extend their monopoly in the market. In order to implement the above goal and to gain the broadest possible protection originator companies have to employ tactics that will: (a) guarantee protection of their product at least until the end of the patent protection period of the base patent in cases where generic companies attempt to invalidate the base patent; and (b) extend the exclusivity period beyond the expiry date of the basic patent. ${ }^{55}$

\footnotetext{
$51 \quad$ ibid 24 'the median number of patents covering each drug was roughly three per drug while the median number of patents pharmaceutical companies licensed was one, and the highest number of licenses was three'.

$52 \quad$ ibid 7.

53

Case

AT.39612

Perindopril (Servier)

$<$ http://ec.europa.eu/competition/elojade/isef/case_details.cfm?proc_code=1_39612 > (accessed 20 July 2016).

Communication from the Commission, 'Guidance on the Commission's enforcement priorities in applying Article 82 of the EC Treaty to abusive exclusionary conduct by dominant undertakings' (2009) OJ C 45/7. According to para. 19 of the Guidance, the adverse impact on consumer welfare may be in the form of higher price levels than would have otherwise prevailed or in some other form such as limiting quality or reducing consumer choice. 184, para 475 <http://ec.europa.eu/competition/sectors/pharmaceuticals/inquiry/staff_working_paper_part1.pdf > (accessed 20 July 2016).
} 
Under the first scenario, in order to maximise patent coverage on commercially valuable products and ensure exclusivity at least until the expiry of the basic patent on a newly invented drug compound, originator companies may file a multitude of patent applications. This additional filing of patent applications will cover any potentially commercially important aspect of products such as processes, formulations, additional pharmaceutical or other indications and salts/solvates/physical forms (socalled 'secondary' or 'subsidiary' patent protection). ${ }^{56}$ As a result of this patent filing practice, the originator will create several layers of defence. Thus, where generic companies might manage to invalidate the basic patent before it expires they still might have difficulties with entering the market if the originator company has succeeded in strategical accumulation of secondary patents. ${ }^{57}$

In order to succeed in the second scenario and to extend the protection beyond the expiry of the basic patent, an originator company may obtain numerous patents (on process, reformulation, etc.) protecting the product during and towards the end of the life of the basic patent. Such practice is aimed at keeping generics off the market even after the basic patent has expired. ${ }^{58}$

The consequence of maximising patent coverage in such a way is the creation of a web of patents, ${ }^{59}$ i.e. the portfolio of rights that protects the different product features of a single medical product ${ }^{60}$ In this case, any attempt to develop a generic version of the drug in salt, crystalline or amorphous forms would inevitably infringe a patent for the relevant form of the drug. ${ }^{61}$

An additional way to enhance patent portfolios is through pending applications. Under certain circumstances, originator companies may also multiply the number of pending applications by filing for divisional patent applications. This may be done by dividing out from a parent patent application one or several (narrower) applications, which will then have a procedural life of their own. ${ }^{62}$ Despite the fact that such divisions will not extend the protection period of the parent application, ${ }^{63}$ they nevertheless increase uncertainty for the generics.

\subsection{How do secondary patents protect basic patents?}

In order to understand the mechanism of this practice and therefore the motivation to use it by originator companies, it is important to answer a few crucial questions: (a) How does a secondary patent fence a basic patent and/or product covered by this basic patent?; (b) How can a cluster of secondary patents preclude generics from entering the market?; (c) Can a generic version of an expired basic patent

\footnotetext{
$56 \quad$ ibid 189 , para 491.

57 ibid 184, para 476; see also Lars Kjølbye, 'Article 82 EC as Remedy to Patent System Imperfections: Fighting Fire with Fire?' (2009) 32(2) World Competition 163, 167.

$58 \quad$ Pharmaceutical Sector Inquiry (n 55) 185, para 477.

59 ibid 189, para 492.

60 Marc P. Philipp, 'Intellectual Property Related Generic Defense Strategies in the European Pharmaceutical Market. Implication of the EU Commission's Sector Inquiry from an IP, Competition Law and Economic Perspective'(2011) MIPLC Studies 51.

61 Pharmaceutical Sector Inquiry (n 55) 189, para 492.

62 ibid 187 , para 481.

63 ibid.
} 
infringe on a secondary patent?; (d) How do secondary patents extend the protection of a product beyond the life of a basic patent?

According to the pharmaceutical industry's view voiced by the EFPIA,${ }^{64}$ the basic legal principle should be taken into account, which is that patents granted on further inventions made in relation to already patented subject matter can never extend the scope or term of patent protection of an earlier patent. ${ }^{65}$ It is claimed that the scope of a secondary patent is limited to new inventions, and its existence does not prevent third parties from exploiting the full scope of the expired patent. ${ }^{66}$ Therefore, it seems that the answers to the questions posed above are that secondary patents cannot protect a basic patent, cannot extend the life of a basic patent, and cannot preclude generics of a product protected by a basic patent from entering the market; likewise, generics of a basic patent cannot infringe secondary patents. If this is so, the following question emerges: why are pharmaceutical companies so keen to accumulate numerous patents on a successful product?

While this position has a strong legal standing supported by the patent law provisions, it seems that the way pharmaceutical companies use the patent system might suggest the opposite answers. Some authors, as well as the Commission, ${ }^{67}$ in fact support this opposite view. Thus, it is argued that the protection of the exclusivity of a base invention by filing a multitude of dependant improvement patents, which form a 'fence' around the principal patents, ${ }^{68}$ can produce an interdependence in that improvement patents and block the exploitation of the principal patent in the same way as the exploitation of the latter, legally speaking, blocks the exploitation of the improvement patents. ${ }^{69}$ As a result, if the generics decide to enter the market when the basic patent expires or is invalidated, it may still infringe on one of the dependent secondary patents held by the originator and thus face an infringement lawsuit.

\subsection{Example of strategic accumulation of patents - the Perindopril case}

The Perindopril case is a classic example of strategic accumulation of patents by a pharmaceutical company for the exclusionary purposes. It is also a unique case, as for the first time the EU Commission discussed this practice in its decision.

In 2014 the EU Commission found that Les Laboratories Servier, a French pharmaceutical originator company, violated EU competition law by engaging in patent acquisitions and reverse payment

64 European Federation of Pharmaceutical Industries and Associations.

65 EFPIA, 'The degree to which patenting, and in particular secondary patenting, protect pharmaceutical products during their lifecycle is often misconstrued' (28 November 2012) <http://www.efpia.eu/blog/9/71/The-degree-to-whichpatenting-and-in-particular-secondary-patenting-protect-pharmaceutical-products-during-their-lifecycle-is-oftenmisconstrued $>$ (accessed 20 July 2016).

66

ibid.

Pharmaceutical Sector Inquiry (n 55) 183-185, paras 467-477; see also Tahir Amin and Aaron S. Kesselheim, 'Secondary Patenting Of Branded Pharmaceuticals: A Case Study Of How Patents On Two HIV Drugs Could Be Extended For Decades' (2012) 31 (10) Health Affairs 2286 <http://content.healthaffairs.org/content/31/10/2286.long> accessed 10 May 2016> (accessed 20 July 2016).

Hanns Ullrich, 'Strategic Patenting by the pharmaceutical industry: towards a concept of abusive practices of protection' in Josef Drexel and Nari Lee (eds), Pharmaceutical Innovation, Competition and Patent Law (Edward Elgar Publishing Ltd, 2013) 250.

ibid. 
settlements with respect to its most successful blockbuster drug Perindopril, an angiotensin converting enzyme inhibitor used for the treatment of cardiovascular diseases (e.g. high blood pressure) ${ }^{70}$ In its decision the Commission drew a broad picture of Servier's anti-generics strategy that had the objective to delay or prevent generic entry by making use of a great variety of instruments. As one of the most important elements of Servier's anti-generics strategy, apart from the patent acquisitions and reverse payment settlements, the Commission also described applications for and obtainment of a number of process and crystalline form patents.

As the Commission explained, generic entry on the most important markets, such as the UK and France, should have happened, in principle, after expiry of the perindopril compound patent (including its SPC) in 2003 and 2005 respectively. However, because of its anti-generic strategy, the actual generic entry, for instance to the UK market, occurred only in 2007, i.e. with a four year delay. ${ }^{71}$ The initial patent protection of perindopril was based on several key patents that cover its basic compound, as well as its processes of production and synthesis. In particular, the patent on the perindopril compound was due to expire in September 2001, but it was further extended by SPCs in the UK till 2003 and in France till 2005. Additionally, in the 1980s Servier obtained five patents on the key processes of industrial preparation and synthesis of perindopril (one of them was due to expire in 2001 and four others in 2008). Servier knew that after the expiration of the compound patent, it could only rely on the protection of its process patents, which described the specific processes by which Servier produced perindopril. However, Servier was not confident in relying solely on these process patents, as they would not afford absolute protection against generic entry, because competitors might develop alternative non-infringing production processes. $^{72}$

Therefore, it was decided to strengthen the patent protection for perindopril by means of filing for blocking patents. The timing was also crucial - as the patent applications are only published 18 months after filing, it was important that a publication of the new process patents is made before October 2001 (the expiration of the compound patent) in order to inform third parties about the additional protection of the drug. ${ }^{73}$ The strategic objective was to neutralise the arrival of generics through blocking all the non-infringing alternatives that can potentially be industrialised. ${ }^{74}$ Therefore, the Sevier's patenting strategy consisted of filing of numerous patents that covered all aspects associated with the molecule, its alternatives of synthesis routes, production processes, polymorphic forms, etc. Eventually, Servier was successful in establishing a dense network of patents around perindopril. ${ }^{75}$

Serveir's internal documents revealed that of the 33 process patents (mostly patents for synthesis routes), 21 were internally described by Servier as 'blocking patents' or 'paper patents'. Three of these 21 process patents were in addition characterised as involving 'zero inventive step'. Nevertheless, these

\footnotetext{
70 Case AT.39612 - Perindopril (Servier) <http://ec.europa.eu/competition/elojade/isef/case_details.cfm?proc_code=1_39612> (accessed 20 July 2016).

71 ibid, para 4: 'Servier noted on the eve of actual generic entry in July 2007, that its anti-generics strategy had been very successful: "*4 years gained = great success"”.

72 ibid, para 115.

73 ibid, para 114-116.

74 ibid, para 117.

75 ibid, para 118
} 
patents were granted by the EPO. ${ }^{76}$ Server considered these patent applications filings as a purely editorial task, i.e. without conducting any patentability studies or any laboratory trials. ${ }^{77}$

The Commission concluded in its decision that ' $[\mathrm{t}]$ hese patent applications and ensuing patents made it more difficult, costly and lengthy for potential entrants to identify the scope of Servier's valid patent protection and thus develop a viable product for potential entry'. ${ }^{78}$ Summarising all the discussion about the various strategies used by Servier, including strategic accumulation of patents, the Commission emphasised that, 'whatever the legal tool ultimately used in each particular case, Servier used all available means to eliminate close threats one after the other as the only way and with the single objective of preventing and/or delaying generic entry on the market and the ensuing collapse of its revenues' ${ }^{79}$ The Commission, however, further concluded that ' $[\mathrm{t}]$ he decision does not qualify each and every one of these practices as infringements but they all form part of Servier's overall and comprehensive strategy against generic companies' ${ }^{80}$

The Perindopril example shows that the main purpose of strategic accumulation of patents is the protection and maintaining of a monopoly on the market and stifling competition by delaying or blocking generic competition. However, despite the crucial role of this strategy in the success of the overall anti-generic strategy and its apparent anticompetitive effect, the Commission decided not to address Servier's strategic accumulation of patents in its assessment of the anticompetitive practices discussed in the decision, confining the analysis only to the condemnation of the Servier's patent acquisitions and reverse payment settlements.

\subsection{Why do pharmaceutical companies accumulate patents?}

Broadly speaking, the intended effect of strategic accumulation of patents, as analysed above, is to prevent or delay generic entry. While this, during the period of exclusivity, is generally in line with the underlying objectives of the patent system, it may in certain cases only be aimed at excluding competition and not at safeguarding a viable commercial development of a company's own innovation. ${ }^{81}$

The above analysis shows that strategic accumulation of patents bears three main functions. First, by using multiple incremental patents the originator ensures that its market exclusivity is maintained in case its basic patent expires or is invalidated by a generic company. The denser the web created by this strategy, the more difficult it will be for a generic company to bring its generic version of the original pharmaceutical to the market. ${ }^{82}$ Therefore, even though the main patents protecting the product have expired, the generic version may still infringe one of the multiple patents surrounding the original

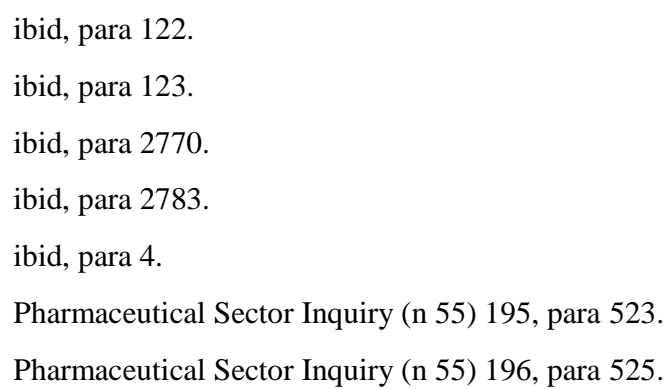


pharmaceutical. ${ }^{83}$ This can occur either because patents cover all economically interesting or viable salt forms, enantiomers or formulations of the compound, or all efficient methods of its manufacture. ${ }^{84}$

Second, this practice protects product market share by increasing uncertainty for a generic company with respect to the time when a generic company may launch its product without infringing any patents from the originator's patent portfolio. Dense webs of patents, set up at the right time (towards the end of the exclusivity period of an active substance), would prevent the market entry of generics: these secondary patents would block the majority of, if not all, commercially interesting market openings for the exploitation of the active substance, or they would block efficient production processes. ${ }^{85}$ This blocking effect would not necessarily result from a complete coverage of all the modes of utilisation and production of the active substance, but above all from the uncertainty concerning the existence and the dimension of the gaps within this network of secondary patents. ${ }^{86}$ Consequently the very existence of these secondary patents impedes the rapid entry of generic products on the market. ${ }^{87}$ As a result, such legal uncertainty extends the market exclusivity of a drug beyond the basic patent protection.

Third, this practice helps to maintain companies' freedom to operate. Patenting around a core technology in itself has no direct commercial purpose, but the technological field becomes unattractive for any potential market entrant and ensures that the company will not be locked out of a future technological development by its competitors. ${ }^{88}$ Among other functions of this strategy is that it may, without any enforcement action by originator companies, delay generic entry until the patent situation is clearer, or even discourage more risk-sensitive generic companies from entering altogether. ${ }^{89}$ Additionally, portfolios of incremental patents may serve as a legal ground for patent infringement litigation against generic companies; again, this may keep generics off the market for a substantial period of time. Finally, all the above-mentioned functions of strategic accumulation of patents raise search, transactional, legal and market entry costs for generics.

\section{Patent thickets in complex technologies and strategic accumulation of patents in the pharmaceutical industry are different practices}

The above analysis of the two sets of practices in complex technology industries and in the discrete technology pharmaceutical industry allows to conclude that the strategy identified by the European Commission as patent thickets in the pharmaceutical industry has, in fact, a different nature as compared to the traditional concept of patent thickets. At first glance these two phenomena might share similar features and, if graphically described, might indeed look alike: they both appear as a dense web of overlapping patents. However, in reality they are different and therefore require different approaches by the competition authorities.

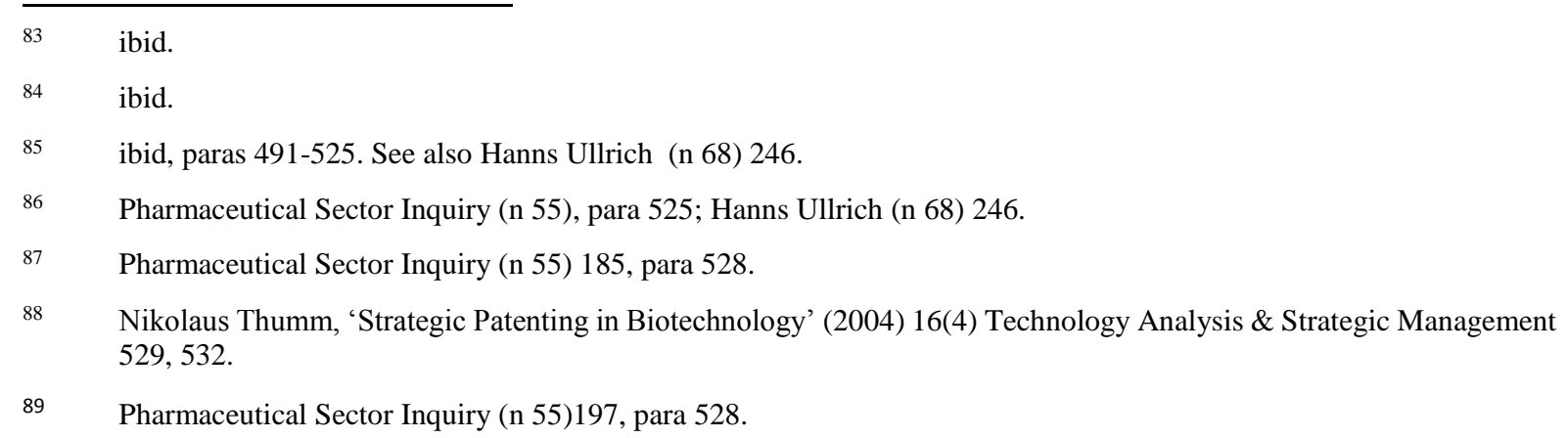


As we have already seen, patent thickets arise in complex technologies and possess their specific features, which are a dense web of patents with overlapping claims that protect multiple compounds of a complex product; these patents belong to multiple patent holders. Most importantly, this dense web arises unintentionally due to: (a) institutional flaws, such as a lack of necessary recourses, which lead to patents with a broad and uncertain scope being granted; and (b) business strategies of numerous participants in patent thickets aimed at increasing a number of patents in their patent portfolios in order to gain some bargaining power, block competitors or serve defensive purposes. These features of patent thickets reinforce the suggestion that patent thickets in complex technologies are indeed the natural outcome of the patent system functioning and should be resolved through the means of the patent system.

As was mentioned previously, the phenomenon identified by the Commission shares some common features with the patent thickets concept: it also has a dense web of overlapping patents, which occur due to the institutional gaps described above. However, it is different from patent thickets in a number of ways. Firstly, this dense web of patents is created by and belongs to a single firm, the originator, as opposed to the multiple participants in complex technology patent thickets. Secondly, this dense web is created by the originator in order to protect its basic patent, which covers a commercially valuable product, as well as to extend the protection beyond the basic patent A substantial difference here is in the nature of a product - it is discrete, i.e. consists of an active ingredient that is protected by a basic patent. In order to protect this active ingredient, the originator company builds up multiple layers of defence by means of applying for numerous incremental patents. Therefore, the classic model of strategic accumulation of patents in the pharmaceutical industry is: (1) multiple secondary patents on a (2) basic compound (3) held by a single originator company. Thirdly, unlike in complex technologies, the originator maintains exclusive rights over its patent portfolio. Therefore, the originator does not need to cooperate with its competitors and is free to operate in the field, protected by its numerous patents. Fourthly, with respect to patent thickets, business strategies of patent holders are not aimed at the creation of patent thickets per se. On the contrary, in the pharmaceutical industry the creation of a web of patents is an intentional action of the originator for the sole purpose of protecting valuable products from generic market entry. It is a strategic exclusionary behaviour of a pharmaceutical company intended to block or delay generic entry. Fifthly, the aim of such a dense web of patents in the pharmaceutical sector is not to strengthen bargaining and licensing position, as is normally the case in complex technologies industries, but to block the competitor from entering the market for as long as possible.

Finally, in complex technologies, if patent owners fail to cooperate (e.g. to cross-license or to create a patent pool), they will reach a deadlock that will be detrimental to all the participants. As a result of such a failure to cooperate, the manufacture of a product that consists of multiple fragmented intellectual property rights owned by numerous owners will be blocked. Therefore, in complex technology the patent holders involved in patent thickets are forced (and indeed it is in their own commercial interests) to cooperate or they will be unable to produce a product and/or will face litigation. In the pharmaceutical industry, the situation is different - the creation of a dense web of patents is from the outset focused on reaching a deadlock that will keep the competitor off the market. Therefore, it is true that the mechanisms that worked 150 years ago are still valid for complex technologies - patent owners have substantial incentives to overcome a patent thicket through the private mechanisms discussed above. ${ }^{90}$ 
However, such mechanisms will not be able to resolve the problem of strategic accumulation of patents in the pharmaceutical industry and, therefore, regulatory solutions should be applied. In other words, taking into account the different aims and mechanisms of creation of these two concepts, it is obvious that the solutions that were developed for complex technology will not work in the pharmaceutical industry, and vice versa.

\section{Why is it important to distinguish patent thickets from strategic accumulation of patents?}

The differentiation of patent thickets from strategic accumulation of patents is crucial when it comes to the antitrust analysis of the respective behaviour of a pharmaceutical company. When dealing with patent thickets, the main task of competition authorities is to control cooperation between competitors in order to avoid collusion. In general, however, patent thickets in complex technologies are treated as a flaw of the patent system. As a result, although it is agreed that some improvements to the patent system must be undertaken, it is assumed that market participants can resolve the problem of patent thickets by means of cooperation.

On the contrary, strategic accumulation of patents in the pharmaceutical industry is not solely a deficiency of the patent system. Unlike in complex technologies where the analysis of patent thickets focuses either on the circumstances of their occurrence ${ }^{91}$ or patent compliance by the newcomer ${ }^{92}$ the strategic accumulation of patents in the pharmaceutical industry should be centred on the behavioural unilateral aspect of the originator, which intentionally and strategically accumulates patents in order to block generic entry. Therefore, strategic behaviour of pharmaceutical companies that (ab)use the patent system in order to extend their monopoly for as long as possible substantially delaying generic competition should be adequately addressed by the competition authorities.

\section{The role of patent law and competition law in strategic accumulation of patents}

The argument, articulated by pharmaceutical companies protecting the legality of strategic accumulation of patents, is that these IP strategies are in line with patent law, and therefore legal. If the invention meets the patentability requirements, i.e. it is new, involve an inventive step and is susceptible of industrial application, ${ }^{93}$ then the company is entitled to a patent. And once the patent is granted the owner has the right to protect its invention by excluding its competitors.

However, such a position does not take into account the abuse of the patent system in general. Patent law is neither equipped with the necessary legal tools that would enable it to deal with the abusive practices, nor it is the aim of this law. The purpose of patent filings, as well as the further use of these patents, is beyond the scope of the patent system. ${ }^{94}$

\footnotetext{
$91 \quad$ B.H.Hall et al. (n 12).

92 Robin Jacob (11).

93 Article 52(1) of the European Patent Convention 2000.

94 Duncan Matthews and Olga Gurgula, 'Patent Strategies and Competition Law in the Pharmaceutical Sector: Implications for Access to Medicines' European Intellectual Property Review, Forthcoming; Queen Mary School of Law Legal Studies Research Paper No. 233/2016, available at SSRN <http://ssrn.com/abstract=2779014>.
} 
On the other hand, competition law is well-equipped to deal with such practices. Anti-competitive practices of pharmaceutical companies that enjoy a dominant position are dealt with under Article 102 of the TFEU that condemns abuses of such monopoly, including abuses of intellectual property rights. Despite being a legal monopoly, intellectual property should not escape competition law enforcement when the exercise of IP is deemed anti-competitive. These provisions may also be relevant to strategic patenting when this practice eliminate generic competition and have adverse impact on consumer welfare. ${ }^{95}$

It is also important to note, that accumulation of patents should not be automatically condemned as a violation of competition law, as a company that creates its patent portfolio may pursue a perfectly legitimate aim of protecting its inventions. Therefore, when analysing strategic accumulation of patents by a pharmaceutical company it is important to consider its effect on competition and consumer welfare.

\section{Conclusions}

Strategic accumulation of patents in the pharmaceutical industry is a practice that is actively used by pharmaceutical companies in order to protect and extend exclusive rights on their products. This practice allows to effectively block generic competition and as a result to maintain monopoly prices to the detriment of consumers. Although the negative effect of this practice was identified by the European Commission in 2008 (despite the Commission erred in the definition of this practice), as well as its anticompetitive nature is widely discussed by legal community and the international organisations, ${ }^{96}$ it has not been addressed by the competition authorities. The main reason for such hesitation is a concern that the fragile balance between the facilitation of innovation and protection of public interests will be disturbed. It is, however, believed that this concern may be pacified by a carefully crafted competition law analysis of a particular practice and its effect on competition on a case-by-case basis.

However, before turning to the competition law analysis it is first important to define the practice and dissociate it from another concept that, although has some similar features, is in fact a different notion. The aim of this paper, therefore, was to make this first step, i.e. strategic accumulation of patents in the pharmaceutical industry was detached from the patent thickets in complex technology industries. It is hoped that the conclusions made in this paper will help to attract attention of the competition authorities to the problem of strategic accumulation of patents in order to prevent abuses of the patent system by pharmaceutical companies for the benefit of the consumer welfare.

\section{References}

Amin T and Kesselheim A S, 'Secondary Patenting Of Branded Pharmaceuticals: A Case Study Of How Patents On Two HIV Drugs Could Be Extended For Decades' (2012) 31 (10) Health Affairs 2286

95 ibid.

96 See, for example WTO, WIPO, WHO, 'Promoting Access to Medical Technologies and Innovation: Intersection between public health, intellectual property and trade' (2012) 76 <https://www.wto.org/english/res_e/publications_e/who-wipo-wto_2013_e.htm.> (accessed 10 July 2016); see also Duncan Mathews and Olga Gurgula, 'Submission to the UN High-Level Panel on Access to Medicines: The importance of competition law in facilitating access to medicines' (2016) <http://www.unsgaccessmeds.org/list-ofcontribution/>. 
<http://content.healthaffairs.org/content/31/10/2286.long> accessed 10 May 2016> (accessed 20 July 2016).

Burk D L and Lemley M A, 'Policy Levers in Patent Law' (2003) 89 VA. L. REV. 1575, 1625-27.

Carrier M A, 'A Roadmap to the Smartphone Patent Wars and FRAND licensing' (2012) 2(4) CPI Antitrust Chronicle 7.

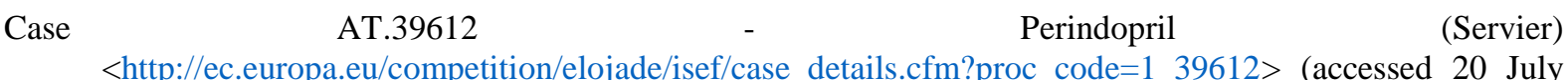
2016).

Clarkson G and Dekorte D, 'The Problem of Patent Thickets in Convergent Technologies' (2006) 1093 Annals of the New York Academy of Sciences 180.

Cohen W M et al., 'Protecting their intellectual assets: Appropriability conditions and why U.S. manufacturing firms patent (or not)' (2000) 7552 NBER working paper, Cambridge, MA.

Communication from the Commission, 'Guidance on the Commission's enforcement priorities in applying Article 82 of the EC Treaty to abusive exclusionary conduct by dominant undertakings' (2009) OJ C 45/7.

EFPIA, 'The degree to which patenting, and in particular secondary patenting, protect pharmaceutical products during their lifecycle is often misconstrued' (28 November 2012) <http://www.efpia.eu/blog/9/71/Thedegree-to-which-patenting-and-in-particular-secondary-patenting-protect-pharmaceutical-productsduring-their-lifecycle-is-often-misconstrued $>$ (accessed 20 July 2016).

Entezarkheir M, 'Patent Thickets, Spillovers, and Market Value: Evidence from a Panel of US Firms' (2008) < https://editorialexpress.com/cgi-bin/conference/download.cgi?db_name=IIOC2009\&paper_id=165> (accessed 20June 2016).

EPO Report, 'Economic and Scientific Advisory Board Workshop on Patent Thickets' (Leuven, 26 September 2012)

<http://documents.epo.org/projects/babylon/eponot.nsf/0/B58781F239B083CEC1257B190038E433/\$FI LE/workshop_patent thickets en.pdf $>$ (accessed 20 July 2016).

European Commission, 'Pharmaceutical Sector Inquiry, Preliminary Report' (2008).

European Commission, 'Pharmaceutical Sector Inquiry: Final Report' (8 July 2009) (Pharmaceutical Sector Inquiry) $184, \quad$ para 475 〈http://ec.europa.eu/competition/sectors/pharmaceuticals/inquiry/staff_working_paper_part1.pdf> (accessed 20 July 2016).

Evans D S and Layne-Farrar A, 'Software Patents and Open Source: The Battle over Intellectual Property Rights' (2004) 9 VA. J.L. \& TECH. 10.

FTC Report, 'To Promote Innovation: The Proper Balance of Competition and Patent Law and Policy' (2003).

Ganslandt M, ‘Intellectual Property Rights and Competition Policy’ (2008) 726 IFN Working Paper.

Hall B H et al., 'A Study of Patent Thicket' (2013) UK IPO.

Howe H, 'Adventures and Achievements of Americans' (Cincinnati, Henry Howe 1859).

Heller M, 'The Tragedy of the Anticommons: Property in the Transition from Marx to Markets' (1998) 111 HARV. L. REV. 621.

Jacob R, 'Patent thickets: a paper for the European Patent Office Economic and Scientific Advisory Board Meeting' (2013) 8(3) Journal of Intellectual Property Law \& Practice 206.

Kjølbye L, 'Article 82 EC as Remedy to Patent System Imperfections: Fighting Fire with Fire?' (2009) 32(2) World Competition 163.

Lampe R L and Moser P, 'Do patent pools encourage innovation? Evidence from the 19th-century sewing machine industry' (2010) 70 Journal of Economic History 898-920.

Lewis J I D, 'The sky is not falling: Navigating the smartphone patent thicket' (WIPO Magazine, February 2013) <http://www.wipo.int/wipo_magazine/en/2013/01/article_0002.html> (accessed 20 July 2016). 
Matthews D and Gurgula O, 'Patent Strategies and Competition Law in the Pharmaceutical Sector: Implications for Access to Medicines’ European Intellectual Property Review, Forthcoming; Queen Mary School of Law Legal Studies Research Paper No. 233/2016, available at SSRN < http://ssrn.com/abstract=2779014 >.

Matthews D and Gurgula O, 'Submission to the UN High-Level Panel on Access to Medicines: The importance of competition law in facilitating access to medicines' (2016) <http://www.unsgaccessmeds.org/list-ofcontribution/>.

Mossoff A, 'The Rise and Fall of the First American Patent Thicket: The Sewing Machine War of the 1850s' (2011) 53 Arizona Law Review 165 < http://papers.ssrn.com/sol3/papers.cfm?abstract_id=1354849> (accessed 20 July 2016).

Philipp MP, 'Intellectual Property Related Generic Defense Strategies in the European Pharmaceutical Market. Implication of the EU Commission's Sector Inquiry from an IP, Competition Law and Economic Perspective'(2011) MIPLC Studies.

Shapiro C, 'Navigating the Patent Thicket: Cross Licenses, Patent Pools, and Standard-Setting' in Adam b. Jaffe et al. (eds), Innovation Policy and the Economy 1, 120 (National Bureau of Economic Research, 2001) <faculty.haas.berkeley.edu/shapiro/thicket.pdf> (accessed 20 July 2016).

Thumm N, 'Strategic Patenting in Biotechnology' (2004) 16(4) Technology Analysis \& Strategic Management 529.

UK IPO Report, 'Patent Thickets' (2011) 3 <www.ipo.gov.uk> (accessed 20 July 2016).

Ullrich H, 'Strategic Patenting by the pharmaceutical industry: towards a concept of abusive practices of protection' in Josef Drexel and Nari Lee (eds), Pharmaceutical Innovation, Competition and Patent Law (Edward Elgar Publishing Ltd, 2013) 250.

von Graevenitz G et al., 'How to measure patent thickets - A novel approach' (2011) 111(1) Economics Letters 6-9. doi: 10.1016/j. econlet.2010.12.005.

Werth B, 'The Billion Dollar Molecule: One Company's Quest the Perfect Drug' (1995).

Woolman S et al., 'Evidence on Patent Thickets in Complex biopharmaceutical technologies' (2013) 53(1) IDEA -The Intellectual Property Law Review 6.

WTO, WIPO, WHO, 'Promoting Access to Medical Technologies and Innovation: Intersection between public health, intellectual property and trade' (2012) $76<$ https://www.wto.org/english/res_e/publications_e/whowipo-wto_2013_e.htm.> (accessed 10 July 2016). 